\title{
Evaluation of upper gasutrointesinal DR system for screening
}

\author{
立正佼成会附属佼成病院 放射線室 \\ ○百地佳代冨沢弘至埋橋喜次渡辺雅弘 \\ (Kayo Momochi) (Hiroshi Tomizawa) (Yoshitsugu Uzuhashi) (Masahiro Watanabe) \\ GE 横河メディカル 船木新壽
}

(Shinjii Funaki)

【目的】近年、消化管 X 線検查のデジタル画像の臨床化は、周辺機器の急速な進歩、情報のネットワーク化、 ならびに環境問題等、多くの構想の基に普及の傾向にある。しかし、従来のタイプは透視画像、撮影像の画像 処理等に問題が多く、健診など迅速化が要求される分野での使用は困難だった。今回、ライブ画像を診断に適 応出来るよう設計された GE 社製Precio DSXを基に蹦床評価ならびにデジタル画像の問題点に対し検討を 加えたので報告する。

【方法及び対象】平成 9 年 3 月より 6 月までに行われた上部消化管検查 649 例に対し、透視画像、ライブ像 を中心に検討を加えた。

1 テストチャート抢よびマーゲンファントムによる物理評価 2 臨床時に招ける透視画像の官能評価 3 アナログおよびディジタル画像の比較４3.5インチMOD保管の有用性

【結果及び考察】1 ROC特性は画像少イズの拡大に伴い低下傾向にあったが、解像度では画像の拡大に伴い認 識が容易となり、このことは、消化管検査の対象が、微細化している現在、非常に有効な機能と思われる。

2 透視画像評価シートを基に、4人のスタッフによる透視画像の臨床評価では、体厚の増加とともに、ノイズ の增大、素早い動きに対する残像等、いくつかの問題点が上げられた。

3 撮影画像の視野範囲は、インチサイズが小さくなるにつれ狭くなるが、認識能が高まるため、存在診断に有 効と思われる。画像をズームアップした場合、画像の劣化はさけられないが、I.I サイズの選択により画像 の劣化がさけられるので、ズームの必要な画像に関しては、撮影段階でのI.Iサイズの選択が必要と考える 画像処理には Windowと Levelを個々に調整する方法とWind ow Tap $(-6$ から+6)を変化させる方法があり、 基本的にライブ像を診断に利用できる様、調整がされている。通常は 16 升のチャートが全部識別出来る 0 のレンジに標準調整が行われており臨床画像でも photo 1 に示すような適正濃度の画像を得ることが出来る

。その他、ネカポジ反転、計測等の画像処理機能をもって㧍りキーパットにより簡単に操作が出来るようにな つている。

4 コンピュターによる画像処理の場合、CPU、DISK容量など、ハードの性能が処理時間に大きく影響を及ぼ すが、DSXのHDからMODの転送時間はfig 1 に、3.5 インチMODの保存容量はfig 2 に示す。これは、当 院の健診の検查に十分対応可能であった。

【結論】Window Tapの設定によりライブ像の読影が可能となり、健診のょ うに多数の件数処理にも対応が可能であった。また、DR化により film 搬送 時間が不要なため、㛟查時間が短縮され、1枚あたりの被曝線量も、1/2以 下に軽隇した。さらに画像保存をディスク化する事により、データの保管ス ペースが削隇され、経費も約1/10以下にすることが可能である。透視像に 関しては、被写体厚増加に伴う、ノイズ、残像の影響功增加傾向にあるため、 より自然な画像の構成が必要と思われる。画像処理機能は、画像の持つ信頼 性を考慮した場合、再生装置の性能、再生者の技術レベル等、多くの問題を 含んでいるため Anatomical Reportによる追跡調查を行うと共に、ディジ夕 ル画像の基準を構築し、質的向上に努めていきたいと考える。

\begin{tabular}{|c|c|c|}
\hline$H D \Rightarrow M O D$ & Save 時間 & Retrieve 時間 \\
\hline 圧縮あり & $5.0 \mathrm{~s}$ & $1.7 \mathrm{~s}$ \\
\hline 圧縮なし & $10.0 \mathrm{~s}$ & $4.0 \mathrm{~s}$ \\
\hline
\end{tabular}

fig 1

\begin{tabular}{|c|c|}
\hline & Save Image 画像 \\
\hline $230 \mathrm{MB}$ & 237 画像 \\
\hline $640 \mathrm{MB}$ & 728 画像 \\
\hline
\end{tabular}

fig 2

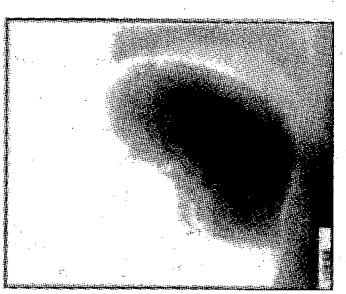

X線写真

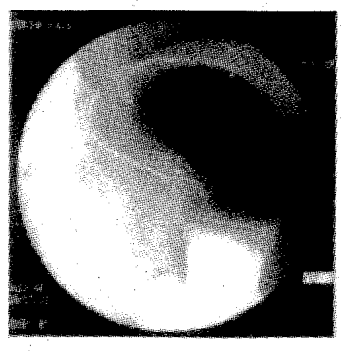

$\mathrm{DR}$

photo 1 